\title{
Н.И. Павлова
}

\section{ОБРАЗ МАРКЕЛА ЩАПОВА В РОМАНЕ Б.Л. ПАСТЕРНАКА «ДОКТОР ЖИВАГО»}

\begin{abstract}
Рассматривается образ Маркела в системе персонажей-дворников и в родственном кругу Громеко - Живаго, частью которого он становится еще до револючии. Выявлены особенности характера дворника, позволившие ему стать всесильным. Проанализированы все ключевые эпизоды с участием Щапова. Установлено, что в Маркеле воплотились черты взятых из жизни «героев» своего времени, представляющих немалую угрозу обществу. Обоснованы выводы, что Живаго сознательно не вступает в конфликт с бездарностью, оказавшейся у власти.

Ключевые слова: Б.Л. Пастернак, «Доктор Живаго», персонажи-дворники, Маркел Щапов, характер, локус, мимикрия.
\end{abstract}

Характеры и судьбы людей из народа, оказавшихся в стихии революции и последовавших за ней событий, в романе Б.Л. Пастернака «Доктор Живаго» (далее - ДЖ) показаны так же широко, как и судьбы представителей интеллигенции. Особую группу «выходцев из простого народа» [1. С. 74] составляют дворники, весьма необходимые и незаменимые в дореволюционной России работники: они следили за порядком на отведенной им территории, помогали жильцам, постовым и околоточным. В романе Пастернака эти функции выполняют Гимазетдин, Филат, Фатима Галиуллина, дворник с рогожею и Маркел. В их отношении к труду, к окружающим людям, в оценке происходящего проявляются личностные и общественно значимые черты их характера. Маркела Щапова отличает «не просто стереотип поведения, а соотнесенная с ним осознанная жизненная позиция» [2. C. 253].

В пастернаковедении нет монографических исследований, посвященных образу Маркела. Отдельные работы [3-5] дают представление о нем как о «холопе, ставшем хозяином», «уплотнителе» [6. С. 17, 61], как «одном из самых узнаваемых представителей нового времени» [7. С. 163]. Между тем этот персонаж отражает в себе эпоху, в которой живет, - явления общественной жизни, нравы и быт. Более того, судьбу дворника Маркела можно описать фразой, характеризующей другого персонажа романа - Лаврентия Михайловича Кологривова, «сказочно далеко шагнувшего выходца из простого народа» [1. С. 74]. Из всех персонажей-дворников только Щапов вырастает до коменданта, что выделяет его. Фигурирует он и во всех ключевых событиях московского периода жизни доктора Живаго (похороны Анны Ивановны (1911), возвращение с фронта (1918), его отъезд с семьей на Урал (1918), возвращение в Москву (1922) и похороны (1929)). Именно поэтому 
Маркел Щапов представляет интерес для исследования как в системе персонажей-дворников, так и «в родственном кругу» Громеко и Живаго, частью которого он стал еще до революции. В связи с вышесказанным считаем необходимым исследовать его роль в сюжете и композиции романа, выявить смысл противопоставления Юрию Живаго, что обусловливает цель настоящей статьи и ее актуальность. Мы руководствуемся методологией анализа, основанной на выявлении внутритекстовых и интертекстуальных связей, определяемых особенностями поэтики и композиции ДЖ: «фрагментарностью и калейдоскопичностью» повествования, «перекличками и переходами одного элемента текста к другому, связанному с ним «отношениями параллелизма и контраста», а также причинно-следственными, метафорическими и метонимическими отношениями [8. С. 5, 7].

В системе персонажей-дворников Филат и «дворник с рогожею»не играют никакой роли в развитии сюжета. Однако в рамках конкретного эпизода оба обнаруживают важность своей профессии, столь необходимой для горожан, а в соположении с Маркелом углубляют отрицательные черты его личности. Очевидно, что Филат пользуется особым доверием, если ему препоручают ключи, просят «присматривать» за мастерскими, «пока суд да дело», кормить попугая и «наведываться» к мадам Гишар в гостиницу [1. С. 54]. У Филата своя система ценностей. Так, несмотря на то, что формально дворник, как и мастерицы, относится к категории забастовщиков, он, в отличие от них, не присоединяется к бастующим, не бросает на произвол судьбы хозяйку мастерских и ее дочь и провожает обеих «в другую часть Москвы» [Там же. С. 52]. В отличие от «дворника с рогожею», молча выполняющего свои обязанности слуги, Филат дважды обнаруживает свое положение маркированной фразой «Слушаюсь, барыня», но это не умаляет его достоинств: он далеко не холоп, о чем говорит его настойчивое разуверение мадам Гишар в том, что выстрелы не холостые. Он и не «дурачок», как она фамильярно называет его, в свойственной господам манере отдавая приказания дворнику: «Захватишь узлы», «присматривай тут», «не забывай», «наведывайся» [Там же. С. 54]. Действия Маркела в аналогичной ситуации отъезда семьи Живаго из Москвы выглядят неблаговидно: его себялюбие и злопамятство на своих «бывших домовладельцев Громеко» привели к тому, что «надзор за комнатами и остающимся в них имуществом поручили» не ему, а «пожилой супружеской чете», в день же отъезда воспользовались «баснословными, копейки не стоившими» [Там же. C. 213] услугами извозчика. В положении Амалии Карловны, попавшей в силу своей беспомощности в зависимость от дворника-слуги, годы спустя оказывается и доктор, и сравнение ситуаций тоже не в пользу Щапова, почувствовавшего безусловное превосходство над Живаго.

Не влияет на ход событий в романе и Гимазетдин, и вряд ли автор стал бы вводить этот образ ради того, чтобы показать еще одну функцию дворников, которые до революции должны были разносить дрова по квартирам. То, что Гимазетдин доставил матери Тиверзина «вчерашний день» полный сарай хороших сухих березовых дров, - его благодарность Куприяну Саве- 
льичу за Юсупку. Данный персонаж входит в роман как «дворник Гимазетдин с тиверзинского двора» [1. С. 31] - места, приковывающего пристальное внимание полиции: здесь «жили рабочие с железной дороги», ссыльнопоселенцы, их дети. В «тиверзинском дворе» формировалось и сознание Лары, близко видевшей здесь бедность и труд, и поэтому, по ее словам, ее отношение к революции иное, чем у Живаго. В этом дворе, по словам же Лары, выросли те мальчики, которые потом оказались в солдатах. В их числе и дворник Гимазетдин, в образе которого воплощается «весь простой народ с тех дворов и из таких же деревень» [Там же. С. 127]. У двора есть адрес - Брестская, двадцать восемь, дважды прозвучавший в романе из уст Лары, потрясенной неожиданной встречей с сыном дворника Гимазетдина Юсупом. Дворник Гимазетдин, таким образом, «приурочен» к определенному месту - локусу «тиверзинский двор», обладающему «психологической реальностью»: он ассоциативно отображает действительность и вызывает в сознании Лары яркие «чувственно-мыслительные представления» [9. С. 91]. Из этого пролетарского локуса выйдут люди, вершившие после революции судьбы: «отзывчивый» «белый генерал» Галиуллин, строгая и непримиримая к врагам председательница домкома Демина, некогда служившая «у Лары Гишаровой мамаши в мастерицах» [1. С. 203], Павел Антипов-Стрельников, способные «уничтожить во имя революционной справедливости» П.Ф. Антипов, ставший судьей, и член ревтрибунала Тиверзин [Там же. С. 405].

Фатима входит в художественное пространство романа в годы революции, и автору важно, на наш взгляд, показать не только типичность судьбы человека из народа, получившего привилегии от советской власти в виде двух светлых комнат на втором этаже. Каждая деталь ее биографии антитетична образу Маркела. Фатима относится к работе не просто добросовестно - дворничиха переживает, «что разложенной на квартиры повинности по уборке двора и улицы никто не соблюдает» [Там же. С. 201]. Она сохранила в себе человеческое достоинство (конфузится в присутствии «товарища Деминой»), не польстилась на продвижение по службе («взмолилась», чтобы ее не переводили «в управдомши»). Зная, кто такой доктор Живаго, не заискивает перед ним. Более того, именно ему она говорит о поступке своего сына, который «плохой дорожкой пошел»: выходец из учеников, из мастеровых, по мысли дворничихи, должен понимать, что «простой народ теперь много лучше стал», поэтому Бог не простит, что пошел против отца, пропавшего в солдатах, убитого, «да как, ни лица не оставили, ни рук, ни ног» [Там же. С. 203]. Человечность Фатимы подчеркивается ее желанием помочь доктору с пролеткой для перевозки больной. Как и ее муж, она «приурочена» к конкретному локусу - дому, которому присваивается «имя товарища Тиверзина, как проживавшего в данном доме до ссылки» [Там же]. Продолжая служить «тиверзинскому двору» вслед за убитым на войне мужем, Фатима объединяет в своем образе семейные ценности, хотя в романе о Галиуллиных как о семье не говорится. Об этом становится известно из уст Живаго, пораженного внешним сходством ма- 
тери и сына. Рефлексия дворничихи (вздрогнула всем телом и побледнела, схватила доктора за руку, просила не губить ее) обнаруживает и чувства матери, и ее характер: она умеет справиться с волнением, найти в себе силы продолжать разговор. Так через судьбу дворника Гимазетдина, оказавшегося в числе многих персонажей романа в годы Первой мировой войны на фронте и погибшего от «немыслимо затянувшихся мучений» [1. С. 119], показана трагическая судьба персонажей, воплощающих конкретные народные типы в истории России начала XX в. А устами Фатимы выражается неприятие событий, происходящих в пределах одного государства: «Разве можно, чтобы господа против господ пошли?» [Там же. С. 203]. Друг против друга пошли и люди, выросшие в одном дворе, дружившие, спавшие в одном блиндаже.

Маркел противопоставляется персонажам своего круга прежде всего своим положением: он дворник состоятельной семьи Громеко. Щапов появляется не во дворе, как Гимазетдин, встречающий «господина» Тиверзина у ворот, не на собрании по «очищению дома», где с «теткой Фатимой» вполголоса беседует председательница, а в доме, куда его приглашают собрать «гардероб черного дерева» [Там же. С. 64]. Более того, он «привел с собой шестилетнюю дочь Маринку» [Там же], что говорит о его привилегированном положении в профессорском доме. Гимазетдин и Маркел вводятся в сюжет романа вместе с детьми, однако персонажей отличает их отношение к ним. Гимазетдин жалеет Юсупку - Маркел «напускается» на дочку: «Да не реви ты, ирод», «Утри сопли да ступай к мамке» [Там же. С. 65]. Оба дворника словоохотливы, однако Гимазетдин не перестает благодарить Тиверзина - Маркел позволяет себе поучать и упрекать упавшую на спину «матушку-барыню». Кажется, что «разошелся» не узел собираемого гардероба, а сам Маркел. Его разглагольствование о своей бывшей профессии перерастает в самовозвеличивание: «Вы не поверите, что этой мебели... через наши руки прошло...» [Там же. С. 65]. Работа дворника для Маркела даже унизительна, потому что его «природная стать столярная» [Там же]. Будучи скорее всего краснодеревщиком, он мог бы выгодно жениться, однако «партии в смысле богатых невест» проплыли, по его выражению, мимо носа, а «всему причина - питейная статья» [Там же]. Маркел, таким образом, появляется в сюжете в статусе дворника дома Громеко, локуса «образованных людей, хлебосолов и больших знатоков и любителей музыки» [Там же]. Дом Громеко - это и «место рождения трагедии» [8. С. 17]: Щапов становится косвенной причиной болезни и смерти матери Тони [10. С. 168], а собираемый им шкап «ассоциативно замыкается» [11. C. 235] на смерти отца и сына Живаго. Мы полагаем, что «гардероб черного дерева» (курсив мой. - Н.П.), символизирующий аристократичность и роскошь, метонимически выражает и гибель сословия, свергнутого революцией. Маркел словно заживо хоронит и дочь Громеко - эмигрировавшую Антонину Александровну, бесцеремонно заявляя жене, что «Тоньки все равно как бы нету» [1. С. 476]. Дом Громеко в Сивцевом Вражке приобретает и характер «ментального феномена» [8. С. 90], в котором отрази- 
лась судьба его хозяев: через год после революции они уже «бывшие домовладельцы Громеко», «бывшие Гарумековы» [1. С. 212, 213], в годы нэпа Юрий вынужден жить в комнатах и «полуразрушенных углах, поразному нежилых и неудобных», потому что из-за высылки его семьи из России «закрепленные за доктором и его домашними комнаты были заселены, из вещей его собственных и его семьи ничего не оставалось» [Там же. С. 472], и оценку этому явлению дает не кто иной, как Маркел. «Тонька», по его выражению, «высланная», «опальная» [Там же. С. 635], а Юрию он без стеснения выговаривает: «Не надо было в Сибирь драть, дом в опасный час бросать. Сами виноваты. Вон мы всю эту голодуху, всю эту блокату белую высидели, не пошатнулись, и целы. Сам на себя пеняй. Тоньку не сберег, по заграницам бродяжествует» [Там же. С. 475]. С разрушением локуса «дом Громеко» происходит перемена и в жизни дворника: «Он перевелся комендантом в Мучной городок» [Там же. С. 472], ассоциативно напоминающий некий хлебный рай. Примечательно, что все убранство его «старой дворницкой с земляным полом» составляют «проведенная вода», «огромная русская печь во всё помещение» и обеденный стол. Ни о каких духовных ценностях, ни о каком созидании родового гнезда речи нет, а безжизненность ее пространства подчеркивает отсутствие в дворницкой окон, этого «символа духовного откровения» человека с миром [10. С. 160]. Между тем сам Маркел уверен в своей компетентности, о чем говорит фрагмент беловой рукописи, в котором Пастернак отмечает не только самоуверенность нового хозяина жизни, но и его амбициозность: называя Тоню «белой негритянкой», «он был убежден, что все это слово [белоэмигрантка] перевирают по непониманию, и только он один исправляет их ошибки и употребляет его правильно» [1. С. 635] (курсив мой. - Н.П.).

Дом в Сивцевом Вражке становится местом, где «восстановление разрушенного» [Там же. С. 65] Маркелом возлагается на Юрия, который лечит Анну Ивановну «наложением рук» [Там же. С. 70]. И несмотря на то, что «с этого падения началось предрасположение Анны Ивановны к легочным заболеваниям» [Там же. С. 65], ей стало лучше на другой же день. Лексике со значением смерти в «наивном эпизоде» [11. С. 234] противостоят звучащие из уст Живаго слова Иоанна Богослова: «Смерти не будет» [1. С. 69]. Связанные причинно-следственными отношениями эпизоды обнаруживают несопоставимость нравственных ориентиров Живаго с жизненными принципами людей, несущими разрушение и смерть. В сцене похорон Анны Ивановны физическому состоянию Юрия - у него жар, беспамятство, близкое к смерти, - противопоставлена физическая сила Маркела. Заметим, что Юрий «спит не проснется в дальнем углу, за высокими книжными полками, доходящими до потолка», а его ищут и не могут доискаться, что аллюзивно строкам Евангелия: «Что ищете Живаго с мертвыми? Он воскрес» (Лк. 24: 5-6), «Смерть уже не имеет над Ним власти» (Рим. 6: 9). В пространстве библиотеки дома Громеко Юрия ищет именно дворник Маркел, и живыл между мертвыми, таким образом, оказывается Юрий Живаго. 
Согласно православному обычаю вынос венков предшествует выносу тела. В сцене похорон эту функцию выполняет Щапов. Венки (лат. corona) в руках Маркела - предметная и символическая деталь, предвосхищающая его власть. Примечательно, что действия Маркела описываются не просто детально (надо тащить вниз на улицу венки, не может доискаться Юры, застрял в спальне) - им посвящена целая глава, что делает дворника безусловным героем в доме Громеко. Его физическая сила сродни богатырской удали, если он «одним ударом расправляется с образовавшимся препятствием» [1. С. 89].

Пастернак изменил характер своего персонажа в эпизоде похорон Анны Ивановны. В карандашной рукописи Маркел показан более человечным: он переживает, чувствуя себя виноватым в ее смерти: «Все эти дни он пьян и все время плачет», «подымает шум и кутерьму» из-за того, что не может вынести самые крупные венки - «по несчастной случайности закрыт из нее [спальни] выход», «уперлась приоткрывшаяся дверца Аскольдовой могилы, проклятого гардероба, с которого начались все горести» [Там же. С. 575] (курсив мой. - Н.П.). Он так же силен, но в его действиях нет желания услужить господам: «Маркел колотит дверью комнаты в дверцу шкапа, пока не проваливает ее внутрь, и бегом в несколько приемов сносит венки вниз по лестнице» [Там же]. В окончательном варианте исключено даже его пьянство. Действия Маркела продуманны, лишены эмоций. Выражения «горою сложенные венки», «вниз по лестнице», «пошел в гору», связанные метонимическими отношениями «процесс - результат», обнаруживают прагматичный характер Маркела, физическая сила и расторопность которого станут залогом его роста в новых условиях жизни. Дом Громеко, таким образом, становится и «сюжетным локусом», «фрагментом пространства» (цит. по: [9. С. 89]), где дворник сначала проворно «сбегает с несколькими венками вниз по лестнице» [1. С. 89], а потом поднимается по лестнице карьерной.

Услужливость позволила Маркелу остаться при хозяевах в Сивцевом Вражке в годы Первой мировой и Гражданской войн, а при советской власти поступить на официальную службу дворника. Именно в этом качестве Маркел и встречает возвратившегося с фронта Юрия. Пастернак акцентирует внимание на новом облачении Щапова - жилетке поверх ситцевой рубахи и дворницком картузе. Суть его, однако, не изменилась - те же хамоватость и воинственность, то же невежество простолюдина. Подобострастие Щапова напоминает поведение Гимазетдина: Маркел бежит от ворот к молодым господам и на бегу, сняв картуз, приветствует Юрия. Однако порядочности Гимазетдина, предупреждающего Тиверзина об опасности, противостоят подличанье и лицемерие Маркела.

Щапов по-своему неглуп: он четко дифференцирует в своей речи глаголы второго и третьего лица, передающие соответственно действия Юрия и Тони: «Не дадут, смотри, мне Антонина Александровна слово сказать, опять, видишь, машут ручкой» [Там же. С. 167] (курсив мой. - Н.П.). Маркел понимает и умеет оценить ситуацию и поэтому груб и прямолинеен 
там, где не могут противостоять его хамству, заискивает перед теми, кого побаивается. Так, в присутствии молодых Живаго он «огрызается на любопытных», обругивает их: «Вылупили белки!», услужливо оберегает супругов от «достопочтенных» прохожих [1. С. 167]. Юрия подобострастно называет Юрочкой, соколиком, в свойственной ему манере фамильярничает с ним, а в удобный момент наушничает на Антонину Александровну, перед которой трусит: «...серчают, слыхал вот. И так завсегда» [Там же]. Чувствуя расположение Юрия, понимая, что у супругов может зайти разговор и о нем, дворник наносит превентивный удар - жалуется на нерасположение к нему Тони, воспроизводя на свой лад ее слова: «Говорят, ты, говорит, Маркел, весь черный изнутре, вот все равно как сажа в трубе» [Там же].

Непорядочность дворника подчеркивается многократно, однако именно в его желании исподтишка очернить Антонину Александровну обнажается его двуличие. Тоня строга с ним, не скрывает, что терпеть не может его «дурацкого тона», убеждена, что он старается угодить, лицемерит, прикидываясь бедным и несчастным ради своей выгоды. Не в ее характере мириться с хитростью, хамоватостью и развязностью Маркела, поэтому, даже зайдя домой, она не успокаивается, раздраженная его навязчивостью, и продолжает разговор, которым начинается новая глава: «Отстал наконец, отвязался. Ты верь ему, верь...» [Там же. С. 168]. Ничем не оправданные на первый взгляд «композиционные разрывы» С. Тюпа сравнивает с «цветаевскими межстрофными переносами» [12. С. 10] и объясняет их постоянно колеблющимся самоощущением Юрия. На наш взгляд, подобный прием композиции позволяет Пастернаку через степень эмоционального напряжения дальновидной Тони выразить суть Маркела и отношение представителей интеллигенции к новому общественному явлению, воплощенному в его образе: «При других всё дурачком, а сам втайне на всякий случай ножик точит. Да вот не решил еще, на кого, казанская сирота» [Там же. С. 167]. Юрий Андреевич, наоборот, держит себя с ним на равных: «Здравствуй, Маркел, давай обнимемся» [Там же]. Видя, что тот не просто бежит, а с дворницким картузом в руке, добродушно говорит: «Да надень ты, чудак, картуз» [Там же]. В отличие от Тони, общающейся с Маркелом не один год и понявшей его социальную опасность, Юрий не вступает с ним в конфликт, склонен верить ему, а паясничанье объясняет пьянством. Маркел для него - часть его семейного круга, поэтому доктор руководствуется в своих поступках совестью, а не эмоциями Тони. Живаго же для дворника - чуждый ему мир интеллигенции, и при первой же возможности он найдет способ выместить свою обиду за нетерпимость Антонины Александровны и снисходительность Юрия Андреевича.

Обеспокоенность автора судьбой интеллигенции, ставшей после революции не только классовым, но и идеологическим врагом пришедшего к власти пролетариата, выражается в углублении противоречий между Живаго и Щаповым. Так, в контексте отъезда их семьи из Москвы становится известно о связи Маркела с милицией, которую он «избрал в качестве политического клуба» [Там же. С. 212]. Быстро сориентировавшийся в ситу- 
ации, связанной с отношением новой власти к интеллигенции, Маркел сменил хозяев. Грамотный деловой стиль изложения его оговора свидетельствует о том, что Щапову помогли его составить. «Он не жаловался, что бывшие домовладельцы Громеко пьют его кровь», а «задним числом упрекал их в том, что все прошедшие годы они держали его в темноте неведения, намеренно скрывая от него происхождение мира от обезьяны» [1. С. 212]. Маркел наверняка припомнил, как Антонина Александровна пеняла ему: «Темная ты личность, Маркел. Пора бы поумнеть» [Там же. С. 167]. Затаил Щапов обиду на Тоню и за то, что не ему препоручила она «надзор за комнатами и остающимся в них имуществом», не через него «пристраивала для сбыта старье, тряпки и ненужную мебель в обмен на дрова и картошку», не его «в последний раз водила по комнатам, показывала, какие ключи к каким замкам и куда что положено» [Там же. С. 211-212].

Беспринципности дворника, который даже после своего доноса вызывается нести вещи на вокзал и обижается, «что отвергают его помощь» [Там же. С. 212], противостоит совестливость Тони по отношению к женщине, на попечение которой она оставляет дом. Чтобы не платить за ее одолжение черной неблагодарностью, Антонина Александровна одаривает ее своими вещами. Описывая состояние Щапова, всячески привлекающего к себе внимание своим скандальным поведением, автор снова использует точку зрения Тони, поскольку только она высказывает возмущение его поведением. Именно против нее и направлен донос Щапова, ставший, возможно, одной из причин высылки семьи Живаго из России. И годы спустя он не забудет своей обиды, презрительно называя эмигрировавшую жену Юрия Тонькой.

Донос Маркела обнаруживает в нем уже классового врага, это его осознанный шаг к продвижению по службе. Поступок дворника аллюзивен доносу Шарикова, обвинившего профессора в том, что тот «произносит контрреволюционные речи, даже Энгельса приказал своей социалприслужнице... спалить в печке...» [13. С. 131]. Подобно Шарикову, Щапов получает полномочия управляющего, причем не заведующего в подотделе МКХ, а коменданта Мучного городка, позволившие ему «во время оно» не только остаться в Москве, но и спастись от ряда декретов и постановлений, принятых в первые годы советской власти, таких, например, как «О порядке реквизиции и обложении имущих классов» [1. С. 378]. Отказавшись от квартиры управляющего, полагавшейся ему «по условиям службы», Маркел процветает в своей дворницкой, где жарко от «дышавшего печного жара» и «туманившегося пара готовившегося варева», в то время как «городской быт все еще не налаживался» и «жильцы Мучного городка ходили неумытыми замарашками, страдали фурункулезом, зябли, простужались» [Там же. С. 473].

Повествование о Маркеле, данное в контексте описания вернувшегося в Москву Живаго, резко контрастирует с образом его жизни: «Маркел пошел в гору и в Сивцевом больше не обретался» - доктор «забросил медицину, превратился в неряху, перестал встречаться с знакомыми» [Там же. С. 472]; в 
дворницкой «огромная русская печь во все помещение», действующий водопровод - у доктора «конец бывшей квартиры Свентицких», достояние которой «составили старая бездействовавшая ванная Свентицких, однооконная комната рядом с ней и покосившаяся кухня с полуобвалившимся и давшим осадку черным ходом» [1. С. 473]. «Чисто внешне» состояние доктора действительно «может быть воспринято как его постепенное падение и социальная деградация» [14. С. 368], однако доктор сознательно «забросил медицину», потому что не хотел приспосабливаться и служить получившим перевес «темным силам "примазавшихся", притворно сочувствующим» [1. С. 405], «новым идолам» [14. С. 367], представителем которых становится Маркел. Щапов, наоборот, «чисто внешне» мимикрировал: сменил дворницкий картуз на полномочия управляющего.

Прием ретардации и ретроспекции позволяет рассказать о жизни Маркела в те годы, когда хлеба давно не было в природе [1. С. 378]. Историю того голодного времени, когда «бесхлебье» «вон из городов погнало» [Там же. С. 311], хранит обеденный стол. На нем «во время оно» руки Маркела «кромсали, кроили, крошили и развешивали хлеб порционно жильцам городка» [Там же. С. 474]. Полномочия управляющего давали ему право распоряжаться и «хлебными купонами квартирантов» [Там же]. За этот стол на правах хозяина Щапов приглашает «покушать горячего» пришедшего за водой Юрия Андреевича. Поведение обедающих выражает отношение к главе семейства и Юрию Живаго и обнажает степень влияния на них Маркела, укоренившего в своих детях и зятьях лакейство: его реплики поддерживаются, а желание доктора «кое-что постирать» вызывает смех.

Характер дворника в эпизоде «В дворницкой» по сравнению с черновыми набросками стал более агрессивным, даже зловещим. Так, Маркел чувствует себя полноправным хозяином не только по отношению к Живаго: Юрию он подыскивает «угол» «из милости», за водою к нему приходили лишь «те из жильцов, которых он к себе благоволил по тем или иным мотивам пускать» [Там же. С. 633], «сам он с женой перебрасывался замечаниями с водоносами, пока те стояли у крана, набирая воду»; во время водоношения доктор «разговаривал с девушками, защищавшими его от Маркеловых презрительных нападок» [Там же. С. 634]. В окончательной редакции показано всесилие персонажа, наделенного особыми полномочиями, позволившими ему «выгородить» доктору «эту крайнюю долю квартиры», в то время как «от Юрия Андреевича шарахались в сторону, как от опасного знакомца» [Там же. С. 473].

События в дворницкой - один из важнейших фрагментов романа, в котором показана трагедия людей, воспитанных укладом жизни прошлого века, столкнувшихся лицом к лицу с представителем новой власти, это кульминация и одновременно развязка во взаимоотношениях Щапова и Живаго. Подобно тому, как «предельно чужд» Живаго «эксплицитно развернутый интерьер» дворницкой Маркела, «сводящий жилое пространство к пространству еды и отсылающий к катастрофической ситуации голода» [10. С. 162], Щапову ненавистен образ жизни и поведение чуждого ему по 
духу Живаго. Зеркальная композиция двух сцен встреч персонажей позволяет увидеть духовную деградацию Маркела. Если в период революции и Гражданской войны дворнику было выгодно служить у господ, для которых он стал частью их жизни, что, однако, не помешало ему написать на них донос, то в годы советской власти появилась возможность расквитаться за все обиды. Будучи и от природы хамоватым, он становится еще более развязным: каждая реплика нового хозяина жизни звучит все унизительнее, едкая ирония переходит в оскорбление, соколик становится вороной, курицыным отродьем, Юрочка - раззявой, Антонина Александровна Тонькой. Между тем Щапов сам выглядит вороной в павлиньих перьях, правда, значительность, которую он себе придает, вызывает у зятьев уважение, что неудивительно, ведь он окружил себя людьми, живущими по принципу: «Ворон ворону глаз не выклюет». Так, зятья «стали удивляться» именно тому, что, узнав от тестя, «кто такой есть» Живаго, не верят. Маркел дважды повторяет это Живаго, словно пеняя ему, что тот сравнялся по своему социальному положению с бывшим дворником, дошел до такого состояния, что, будучи доктором, сам стирает и моет: «Сколько на тебя денег извели! Учился, учился, а какой толк?» [1. С. 475]. С высоты своего положения Маркел резюмирует никчемность существования Юрия Андреевича: «А нешто я тебе повинен, что ты не выдался» [Там же]. Однако Живаго сознательно не вступает в конфликт с Маркелом, понимая, что противостоять посредственности, оказавшейся у власти, практически невозможно. Будучи настоящим русским интеллигентом, Живаго остается самим собой, уступая место бездарности Щаповых, поскольку уже давно «считал себя и свою среду обреченными» [Там же. С. 182]. Воинствующей невежественности бывшего дворника, его грубой прямолинейности может противостоять только Марина. Громкий смех Щаповых, переданный лексическим повтором анафорического типа «За столом захохотали», «Опять за столом захохотали» [Там же. С. 475], прекращается только после того, как «Марина недовольным взором обвела своих, вспыхнула, что-то стала им выговаривать» [Там же]. В беловой рукописи к главе 6 о ней сказано, что она «держалась своего мнения о Юрии Андреевиче. Ее взгляд на него отличался от того, что думали другие» [Там же. С. 635], хотя многого в нем она так и не поняла. Свое отношение Марина выражала, будучи еще шестилетним ребенком, когда «насупленно смотрела на отцову работу» [Там же. С. 64]. Внутренняя сила дочери Щапова заставляет его прислушиваться к ее мнению, принять ее выбор, хотя вряд ли Щапов считал Живаго выгодной партией. Конформизм Маркела проявляется и в том, что он соглашается на двоебрачие зятя.

Портрет Щапова завершает единственная фраза, обнаруживающая его присутствие на похоронах Юрия Андреевича. На скамью к дочери «присаживался отец, тихо всхлипывавший и оглушительно сморкавшийся Маркел» [Там же. С. 491]. Кажется, что он полон сочувствия рано овдовевшей дочери, однако нельзя не заметить, что, будучи всесильным, Маркел не принимает никакого участия в похоронах зятя. Совершенное бездействие 
персонажа обнаруживает новую черту его характера - трусоватое смирение (присаживался, тихо всхлипывал), что объясняется присутствием человека, воплощающего власть. Очевидно и то, что не в характере Маркела оставаться без внимания: он «оглушительно» сморкается [1. С. 491]. На фоне тишины, нарушаемой только «чинными шагами на цыпочках и неосторожным шарканьем прощающихся», общего молчания, «рева голошения» Марины, вырывающегося помимо ее воли [Там же. С. 490], поведение Маркела выглядит не просто неестественно и невежественно, оно демонстрирует торжество посредственности. «Сморкается» на похоронах Анны Ивановны и Фуфков, что не без злорадства отмечают провожающие ее в последний путь, и это вызывает их раздражение. В сцене похорон Юрия Андреевича гиперболизированная автором звуковая деталь контрастна состоянию искренне горюющих и подчеркивает привычку Маркела выдвигать себя в центр событий.

Образ Маркела Щапова занимает весьма значимое место в романе Пастернака, посвященного судьбам людей в истории России начала XX в. Известно, что писатель «мыслит историю не столько фоном для повествования о человеке, сколько особой силой, во взаимодействии и в противоборстве с которой происходит (или не происходит) духовное становление» героев романа «и складываются их судьбы» [6. С. 7]. О духовном становлении дворника Маркела говорить не приходится, хотя, по словам Тони, живет он «не у лабазников» [1. С. 167]. Его не волнуют общественно значимые цели, он и не из тех, кого привлекают «провозглашенные революцией истины» [Там же. С. 473]. Физически сильный от природы, Щапов «богатырствует» не на фронте, зато пронырливость и наушничество выдвигают его в число людей, облеченных властью в годы революции. Осуждая «кабак и бедлант», который «развели» в стране, сам вскоре возглавит коммунальное хозяйство Мучного городка, однако вряд ли озадачится тем, почему «городской быт все еще не налаживался» [Там же]. В Маркеле воплотились черты «героев» своего времени, ловко приспосабливающихся к новым условиям, но в этом «подлаживании» нет «удивительного перехода внутреннего во внешнее», собственного роста, как, например, в Л.М. Кологривове, нет и «выработки и рождения сознания» [Там же. С. 344], что представляет немалую угрозу обществу. Самовозвеличивание Маркелова переходит во всесилие, в торжество бездарности, столь ощутимое после смерти Юрия Живаго. Щапов лицемерен, трусоват, невежествен, агрессивен, озлоблен на тех, кто превосходит его по положению в обществе, уровню интеллекта и воспитания, что не мешает ему, однако, гордиться образованием своей дочери, понимающей «по-иностранному», называть ее «докторшей», сесть на похоронах рядом с горевавшими Дудоровым и Гордоном, явно не смущаясь тем, что не так давно выражал свое презрение Живаго. Тщательность работы Пастернака над данным образом, углубление отрицательных черт, проявляющихся в сравнении его с различными персонажами, говорят о том, насколько писатель обеспокоен судьбой людей, оказавшихся во власти Маркелова, страшных своей посредственностью и заурядностью. 


\section{Лumepamypa}

1. Пастернак Б.Л. Полное собрание сочиненй : в 11 т. М. : СЛОВО/SLOVO. 2004. Т. 4: Доктор Живаго.

2. Теория литературы : учеб. пособие для студентов филол. фак. высш. учеб. заведений : в 2 т./ под ред. Н.Д. Тамарченко. Т. 1 : Н.Д. Тамарченко, В.И. Тюпа, С.Н. Бройтман. Теория художественного дискурса. Теоретическая поэтика. М. : Академия, 2004. $512 \mathrm{c.}$

3. Куиаенко Д.О. Концепт истории как определяющий фактор генезиса персонажей в романе Б.Л. Пастернака «Доктор Живаго» : автореф. дис. ... канд. филол. наук. Краснодар, 2011. $22 \mathrm{c}$.

4. Смирнов И.П. Роман тайн «Доктор Живаго». М. : Новое литературное обозрение, 1996. $208 \mathrm{c}$.

5. Судосева И.С., Тюпа В.И. Мотивика. Интерьеры. // Поэтика «Доктора Живаго» в нарратологическом прочтении / под ред. В.И. Тюпы. М., 2014. С. 250-263.

6. Поливанов $K$. «Доктор Живаго» как исторический роман : дис. ... д-ра филос. $(\mathrm{PhD})$ по русской литературе. Тарту : University of Tartu Press, 2015. 262 c.

7. Павлова Н.И. Маркел Щапов: приемы создания персонажа и его функции в романе Б.Л. Пастернака «Доктор Живаго» // Известия Южного федерального ун-та. Филологические науки. 2018. № 3. С. 158-168.

8. Буров С.Г. Полигенетичность художественного мира романа Б.Л. Пастернака «Доктор Живаго» : автореф. дис. ... д-ра филол. наук. Ставрополь, 2011.

9. Прокофьева В.Ю. Категория пространство в художественном преломлении: локусы и топосы // Вестник Оренбургского гос. ун-та. 2005. № 11. С. 87-94.

10. Судосева И.С. Поэтика интерьера в художественной прозе : дис. ... канд. филол. наук. М., 2016. $191 \mathrm{c}$.

11. Гаспаров Б.М. Временной контрапункт как формообразующий принцип романа Пастернака «Доктор Живаго» // Дружба народов. 1990. № 3. С. 223-242.

12. Тюпа В.И. Художественное целое. Архитектоника и композиция. // Поэтика «Доктора Живаго» в нарратологическом прочтении / под ред. В.И. Тюпы. М., 2014. C. $7-40$.

13. Булгаков М.А. Собрание сочинений : в 10 т. М. : Голос, 1995. Т. 3.464 с.

14. Бертнес Ю. Христианская тема в романе Б. Пастернака «Доктор Живаго»// Проблемы исторической поэтики. 1994. № 3. С. 360-377.

\section{The Image of Markel Shchapov in Boris Pasternak's Novel Doctor Zhivago}

Vestnik Tomskogo gosudarstvennogo universiteta. Filologiya - Tomsk State University Journal of Philology. 2020. 63. 250-263. DOI: 10.17223/19986645/63/14

Natalia I. Pavlova, Saratov State Medical University named after V.I. Razumovsky (Saratov, Russian Federation). E-mail: pim60@mail.ru

Keywords: Boris Pasternak, Doctor Zhivago, yard-keeper characters, Markel Shchapov, character, locus, mimicry.

The article is devoted to the study of the image of Markel Shchapov, the most significant secondary character of Boris Pasternak's novel Doctor Zhivago. This image is considered in the system of yard-keeper characters as well as in comparison with Yuri Zhivago. The juxtaposition of the characters deepens the negative features of the personality of Markel, who prescribes himself undeserved significance, claiming a higher position in society. Strong by nature, he heorizes, but not at the front; his craftiness and tale-bearing promote him to people who were in authority during the revolution. Markel takes an active part in the development of the plot, he appears in all the key events of the Moscow period of the doctor's life. The belligerence, ignorance, and hypocrisy of Markel stand against the kindness and honesty of Zhivago, who returned from the war. The yard-keeper is far from being stupid, he understands 
and knows how to assess the situation and is, therefore, rude and straightforward with the people who cannot resist his rudeness, though he tries to ingratiate himself with those who he himself is afraid of. The essence of the yard-keeper's character and the attitude of the intellectuals to the new social phenomenon, embodied in his image, are expressed by the prudent Tonya, whose adherence to principles provoked Shchapov to denunciation, which reveals him as a class enemy, a person who is consciously seeking promotion. Once he condemned the riots in the country during the revolution, but, during the NEP, Markel himself headed the municipal economy of Flour Town, the life of which, however, he did not adjust to. Events in the yard-keeper's lodge are the most important of the episodes, exposing the tragedy of people brought up according to the way of life of the previous century and faced with the representative of the new government. It is the culmination and the denouement in the relationship of Shchapov and Zhivago at the same time. In the description of the furniture of the yard-keeper's lodge, a special place is given to the dining table, the history of which keeps the past of the yard-keeper, who became omnipotent particularly in the hungry years. The behaviour of the diners expresses their attitude to the head of the family and Yuri Zhivago and reveals the degree of Markel's influence on them. Markel rooted servility in his children and sons-in-law. The portrait of Shchapov is concluded with the phrase, describing his behaviour at the funeral of Zhivago and at the same time revealing his cowardly humility and the habit of attracting attention to himself. The traits of the "heroes" of their time, deftly blending in and adjusting to the new conditions, are embodied in Markel. Having replaced the yard-keeper's cap by the administrator's powers, he still remained a dark, ignorant person. Markel's self-aggrandizement transforms into omnipotence, into the triumph of mediocrity, so meaningful after the death of Yuri Zhivago. The thoroughness of the work on this image, the deepening of the negative features that appear while comparing him with different characters suggest how much the writer is concerned about the fate of people who are in the power of the Markels, terrible for their mediocrity and ordinariness.

\section{References}

1. Pasternak, B.L. (2004) Polnoe sobranie sochineniy: $v 11$ t. [Complete Works: In 11 Vols]. Vol. IV. Moscow: SLOVO/SLOVO.

2. Tamarchenko, N.D. (ed.) (2004) Teoriya literatury [Theory of literature]. Vol. 1. Moscow: Akademiya.

3. Kutsayenko, D.O. (2011) Kontsept istorii kak opredelyayushchiy faktor genezisa personazhey $v$ romane B.L. Pasternaka "Doktor Zhivago" [The concept of history as a determining factor in the genesis of characters in B.L. Pasternak's "Doctor Zhivago"]. Abstract of Philology Cand. Diss. Krasnodar.

4. Smirnov, I.P. (1996) Roman tayn "Doktor Zhivago" ["Doctor Zhivago", a novel of mysteries]. Moscow: Novoe literaturnoe obozrenie.

5. Sudoseva, I.S. \& Tyupa, V.I. (2014) Motivika. Inter'ery [Motivics. Interiors]. In: Tyupa, V.I. (ed.) Poetika "Doktora Zhivago" v narratologicheskom prochtenii [Poetics of "Doctor Zhivago" in a narratological interpretation]. Moscow: Intrada. pp.250-263.

6. Polivanov, K. (2015) "Doktor Zhivago" kak istoricheskiy roman ["Doctor Zhivago" as a historical novel]. Philosophy Dr. (PhD) Diss. Tartu.

7. Pavlova, N.I. (2018) Markel Shchapov: Techniques of Character Creation and Its Function in the Novel by B.L. Pasternak "Doctor Zhivago". Izvestiya Yuzhnogo federal'nogo un-ta. Filologicheskie nauki - Proceedings of Southern Federal University. Philology. 3. pp. 158-168. (In Russian).

8. Burov, S.G. (2011) Poligenetichnost'khudozhestvennogo mira romana B.L. Pasternaka "Doktor Zhivago" [The polygenetics of the artistc world of B.L. Pasternak's novel "Doctor Zhivago"]. Abstract of Philology Dr. Diss. Stavropol.

9. Prokof'eva, V.Yu. (2005) The category of space in the artistic refraction: locus and topos. Vestnik Orenburgskogo gosudarstvennogo universiteta - Vestnik of the Orenburg State University. 11. pp. 87-94. (In Russian). 
10. Sudoseva, I.S. (2016) Poetika inter'era $v$ khudozhestvennoy proze [Poetics of interior in fiction]. Philology Cand. Diss. Moscow.

11. Gasparov, B.M. (1990) Vremennoy kontrapunkt kak formoobrazuyushchiy printsip romana Pasternaka "Doktor Zhivago" [Temporary counterpoint as the formative principle of Pasternak's novel "Doctor Zhivago"]. Druzhba narodov. 3. pp. 223-242.

12. Tyupa, V.I. (2014) Khudozhestvennoe tseloe. Arkhitektonika i kompozitsiya [The artistic whole. Architectonics and composition]. In: Tyupa, V.I. (ed.) Poetika "Doktora Zhivago" $v$ narratologicheskom prochtenii [Poetics of "Doctor Zhivago" in narratological interpretation]. Moscow: Intrada. pp. 7-40.

13. Bulgakov, M.A. (1995) Sobranie sochineniy [Collection of Works]. Vol. 3. Moscow: Golos. pp. 46-136.

14. Bertnes, Yu. (1994) Khristianskaya tema v romane B. Pasternaka "Doktor Zhivago" [The Christian theme in the novel "Doctor Zhivago" by B. Pasternak]. Problemy istoricheskoy poetiki - The Problems of Historical Poetics. 3. pp. 360-377. 